\title{
Total saponins of Tupistra chinensis induce apoptosis in A549 cells
}

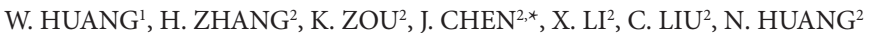

${ }^{1}$ Hubei Key Laboratory of Natural Products Research and Development, Medical College, China Three Gorges University, Yichang 443002, P. R. China; ${ }^{2}$ Hubei Key Laboratory of Natural Products Research and Development, College of Chemistry and Life Sciences, China Three Gorges University, Yichang 443002, P. R. China

*Correspondence: xyyxy1999@yahoo.com.cn

Received February 9, 2012 / Accepted April 18, 2012

\begin{abstract}
Tupistra chinensis Baker has been used as a folk remedy in China, and it has been shown to exhibit anti-inflammation, expectorant and anti-bacterial effects. In this study, we report the cytotoxic activity of the total saponins of Tupistra chinensis Baker (TST) against several carcinoma cell lines, including A549, MCF-7 and HeLa cells with the $\mathrm{IC}_{50}$ values of $4.11 \mu \mathrm{g} / \mathrm{ml}, 6.47$ $\mu \mathrm{g} / \mathrm{ml}$ and $7.78 \mu \mathrm{g} / \mathrm{ml}$ respectively. Treatment of A549 cells with TST resulted in growth inhibition and induction of apoptosis in a time-dependent manners determined by cell viability, chromatin condensation, DNA fragmentation and flow cytometry analysis. The activities of caspase-3, 9 were significantly increased following TST treatment. Real-time PCR analysis showed that the mRNA expression levels of pro-apoptosis related genes including Bax, P21, P27 and P53 were markedly increased in the cells treated with TST but anti-apoptosis related gene Bcl-2 was slightly decreased. TST also leads to a loss of mitochondrial membrane potential in a time-dependent manner the release of cytochrome $\mathrm{c}$ from mitochondria into the cytosol. Thus, these results suggest that TST may play an important role in tumor growth suppression by inducing apoptosis in human A549 cells via mitochondria-dependent apoptotic pathways and the TST would be promising to treat human lung adenocarcinoma.
\end{abstract}

Key words: Tupistra chinensis Baker, total saponins, cytotoxicity, apoptosis, anticancer

Apoptosis, defined as programmed cell death, plays a very important role in many physiological and pathological conditions such as embryo and organ development, immune responses, tumor development and growth $[1,2]$. During past two decades, the molecular mechanism of apoptosis has been extensively studied. Apoptosis may occur via a mitochondriadependent intrinsic pathway which is mediated by Bcl-2 family proteins. Recent studies indicate that apoptosis is involved in a variety of clinical disorders such as cancer and autoimmunity. Many studies have indicated that anti-cancer drugs or cancer chemopreventive agents act through the induction of apoptosis to prevent tumor promotion and progression $[3,4]$. The chemotherapeutic drugs that have been observed to induce apoptosis in vitro include etoposide, camptothecin, VM26, vincristine, cis-platinum, cyclophosphamide, paclitaxel, 5-fluorouracil and doxorubicin [5-7]. Several clinical studies have also shown that chemotherapy triggers apoptotic cell death in patients undergoing chemotherapy $[8,9]$. Thus, identification of potential chemotherapeutic agents using mechanism-based studies holds great promise for elucidating mechanisms and devising more specific and effective treatments for cancer-related diseases.
A wide variety of biological activities from medicinal plants have recently been reported, except for their traditional medicinal effects. Herbal medicines have attracted considerable interests as alternative cancer remedies because of their low toxicity and costs [10]. Tupistra chinensis Baker is growing mostly in southwestern regions of China. As a Chinese folk medicine, the rhizome of this species has usually been used for treatment of headache, pharyngitis, rheumatic diseases, snake-bite and respiratory disorders for a long time [11]. Furthermore, it was specified in "Quality Standard of Herbal Medicines at Hubei Province" (2009 Edition) because of its convinced usages in folk. Previous phytochemical studies have reported the isolation and structural elucidation of several steroidal sapogenins, spirostanol sapogenins, flavans and pregnane genins from the undergroud parts of this plant $[12,13]$. However, studies on the anti-tumor activity and mechanism in vitro of Tupistra chinensis were not yet published. Therefore, the objective of this study is to examine the anti-tumor potential of total saponins in this plant, which was important to develop the plentiful resource of Tupistra chinensis. 


\section{Materials and methods}

Plant and preparation of total saponins. The whole plants of Tupistra chinensis Baker were collected from Shennongjia, Hubei, China and identified. A voucher specimen (No. NP2005004) has been deposited in China Three Gorges University. Total saponins of the rhizome of Tupistra chinensis Baker (TST) were prepared as below. $2.0 \mathrm{~kg}$ of dried Tupistra chinensis rhizome was shivered and refluxed with $95 \%$ ethanol. The concentrated extract was partitioned with acetoacetate and water. Then, the water fraction was added to macroporous adsorptive resins, eluted with 95\% ethanol. Finally, the $95 \%$ ethanol eluant was evaporated and about $80 \mathrm{~g}$ of a yellowish powder was obtained. The dry extract was confirmed to be total saponins using a spectrophotometry method as described [14]. The chemical profile of TST extracts was analyzed using high performance liquid chromatography (HPLC) and is shown in Fig.1. Briefly, compound A, B, C accounted for about 3\%, 5\% and $2 \%$ of TST, and total saponins for $80 \%$, determined by UV spectroscopy at $203 \mathrm{~nm}$. And their structure was determined by IR, MS, NMR spectroscopy.

Cell lines and cell culture. Human lung adenocarcinoma cell line A549, human breast carcinoma cell line (MCF-7) and human cervical adenocarcinoma cell line (HeLa) were purchased from China Center for Type Culture Collection (CCTCC) and cultured in 1640 culture medium supplemented with $10 \%$ fetal bovine serum (FBS) , 1\% penicillin-streptomycin and $0.02 \mathrm{mg} / \mathrm{ml}$ gentamycin in a $5 \% \mathrm{CO} 2$ incubator at $37^{\circ} \mathrm{C}$

Cytotoxicity assay. Cytotoxicity was determined by MTT assay according to a previous method [15]. Briefly, cells $\left(1 \times 10^{4}\right)$ were incubated with different concentrations TST
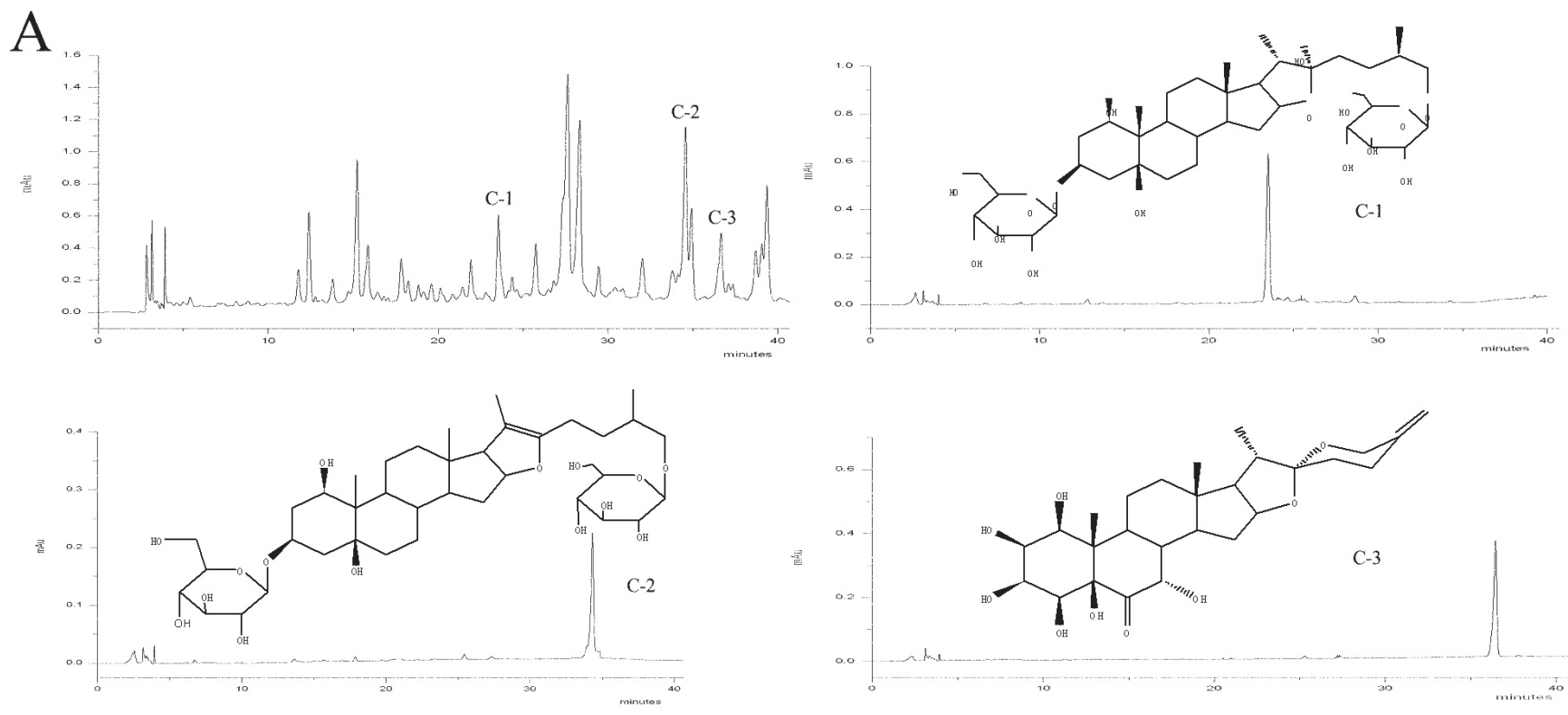

$\mathrm{B}$

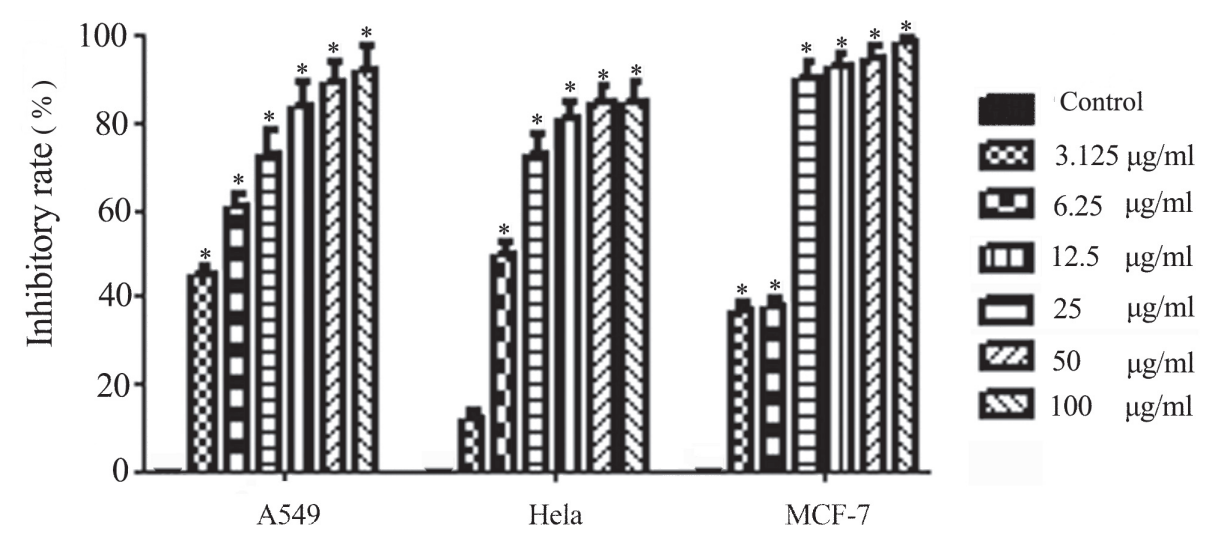

Figure 1. Structures of total saponins of Tupistra chinensis (TST) and their effects on cancer cell lines. (A) The chemical profile of TST extracts and the structures of compound c-1, c-2, c-3. (B) The cytotoxicity of TST on different cell lines was representing as the related inhibitory rate to the control. Values are means \pm SEM $(n=12)$. The shown results were from three independent experiments. ${ }^{*} p<0.05$. 
$(\mathrm{n}=12)$. Controls with non-treated cells were run in parallel $(n=12)$. Following a $48 \mathrm{~h}$ incubation period, the medium was removed and the cells were further incubated for $1 \mathrm{~h}$ in the presence of $50 \mu \mathrm{l}$ of MTT $[0.7 \mathrm{mg} / \mathrm{ml}$ in phosphat buffered solution (PBS)]. After dissolution of the resulting crystal formazan by the addition of DMSO (150 $\mu \mathrm{l}, 1 \mathrm{~h}$ incubation), the absorbance was measured at $490 \mathrm{~nm}$ using an automated microplate reader (ELX 800, Bio-Tek, France). The inhibitory rate was calculated as [(1- At/ Ac) $\times 100]$, where At and Ac are the mean absorbance values of the each treated wells and control respectively.

DNA fragmentation. After the A549 cells were exposed to TST of $10 \mu \mathrm{g} / \mathrm{ml}$ for $4,8,12,16,20$ and $24 \mathrm{~h}$, cell pellets were resuspended in $500 \mu \mathrm{l}$ of lysis buffer $(0.5 \%$ Triton X-100, $10 \mathrm{mM}$ EDTA, and $10 \mathrm{mM}$ Tris- $\mathrm{HCl}, \mathrm{pH} 8.0$ ) at room temperature for $15 \mathrm{~min}$ and centrifuged at $16,000 \times \mathrm{g}$ for $10 \mathrm{~min}$. DNA was then extracted twice with phenol/chloroform (1:1), precipitated with ethanol, and resuspended in Tris/EDTA buffer $(10 \mathrm{mM}$ Tris-HCl, $\mathrm{pH}$ 8.0, and 1mM EDTA). DNA was analyzed after separation by gel electrophoresis ( $1.5 \%$ agarose gel containing $1 \mu \mathrm{g} / \mathrm{ml}$ of ethidium bromide). DNA bands were visualized under ultraviolet illumination and photographed.

Morphological assessment of apoptotic cells. To detect apoptotic cells, A549 cells were stained with Hoechst 33258, exposed to $10 \mu \mathrm{g} / \mathrm{ml}$ TST for $24 \mathrm{~h}$, they were fixed with $2 \%$ paraformaldehyde in PBS for $10 \mathrm{~min}$ at $4^{\circ} \mathrm{C}$, and then washed with PBS. To stain the nuclei, cells were incubated for $10 \mathrm{~min}$ with $20 \mathrm{mg} / \mathrm{mL}$ Hoechst 33258 . After washing with PBS, the cells were observed using a fluorescence microscope (Tokyo, Japan). Cells exhibiting condensed chromatin and fragmented nuclei were scored as apoptotic cells. A minimum of 200 cells were scored from each sample.

Flow cytometry analysis. To quantify the TST-induced apoptotic death of A549 cells, annexin V and PI double staining were performed followed by flow cytometry (FCM; Coulter, Los Angeles, CA, USA). A549 cells $\left(1 \times 10^{6}\right)$ were allowed to attach for $24 \mathrm{~h}$. Then the medium was replaced with an equal volume of fresh medium containing $10 \mu \mathrm{g} / \mathrm{ml}$ TST for 8,16 and $24 \mathrm{~h}$ separately. After the treatment, all cells were collected by trypsinization and washed twice with PBS. The cell suspension was subjected to $400 \mu \mathrm{l} 1 \times$ binding buffer, $5 \mu \mathrm{l}$ annexin $\mathrm{V}$, and $10 \mu \mathrm{l}$ PI stain, and then left in the dark for $15 \mathrm{~min}$. Normally, apoptotic, necrotic, and mechanically damaged cells were determined by FCM with a single beam at $488 \mathrm{~nm}$ excitation wave length. PBS was used as the negative control.
Caspase-3, 9 activity assay. The activity of caspase-3, 9 were determined using the Caspase-3, 9 activity kit (Beyotime, Haimen, China) according to the manufacturer's protocol. The assay is based on spectrophotometric detection of the chromophore, $p$-nitroanilide ( $p \mathrm{NA}$ ), after its cleavage from the labeled substrate, Ac-DEVD-pNA (Caspase-3) or AcLEHD- $p$ NA (Caspase-9). Briefly, A549 cells were lysed after treatment with TST of $10 \mu \mathrm{g} / \mathrm{mL}$ for different time. Assays were performed on 96-well microtiter plates by incubating $10 \mu \mathrm{L}$ protein of cell lysate per sample in $80 \mu \mathrm{L}$ reaction buffer (1\% NP-40, 20mM Tris- $\mathrm{HCl}$ (pH 7.5), $137 \mathrm{mM} \mathrm{NaCl}$, and $10 \%$ glycerol) containing $10 \mu \mathrm{L}$ caspase- 3 , 9 substrate (Ac-DEVDpNA or Ac-LEHD-pNA) (2mM). Lysates were incubated at $37^{\circ} \mathrm{C}$ for $4 \mathrm{~h}$. Samples were measured with an enzyme-linked immunosorbent assay (ELISA) reader at an absorbance of $405 \mathrm{~nm}$ and the caspase activities were expressed as percentage of enzyme activity compared with control. All the experiments were carried out in triplicate.

Real-time Polymerase Chain Reaction. The mRNA expression levels of apoptotic-related genes Bax, Bcl-2, p53 and cell cycle-related genes P21, P27 were carried out using relative-quantitative RT-PCR. The A549 cells were seeded and treated with TST of $10 \mu \mathrm{g} / \mathrm{ml}$ for different time in 6-well plate. Total cellular RNA was isolated from the untreated and treated cells using Trizol reagent. The PCR reaction was carried out on the LightCycler2.0 instrument (software v4.0; Roche Applied Science) using the double-stranded DNA dye SYBR Green I strategy. The oligonucleotide sequences of the PCR primers used were designed based on the human mRNA encoding the respective genes (Table 1). Quantification was based on threshold cycle $(\mathrm{Ct})$ difference performed according to the "delta-delta Ct method" [16], using the following equation: expression ratio $=2^{-\Delta \Delta \mathrm{Ct}}$, where $\Delta \Delta \mathrm{Ct}=(\mathrm{Ct}$ target $-\mathrm{Ct}$ reference) time $\mathrm{x}-(\mathrm{Ct}$ target $-\mathrm{Ct}$ reference) time 0 . The expression level of each target gene was normalized to that of glyceraldehyde-3 phosphate deshydrogenase (GAPDH) which fulfills the requirements for validation of reference genes.

Assessment of mitochondrial membrane potential $(\Delta \Psi \mathrm{m})$. JC-1 Apoptosis Detection Kit (Kaiji, nanjing, China) was used as the detection for determining the changes in the mitochondrial membrane potential, according to the manufacturer's protocol. Cancer cells were firstly incubated with $10 \mu \mathrm{g} / \mathrm{ml}$ TST for 12 $\mathrm{h}$ or $24 \mathrm{~h}$, then, the cells $\left(5 \times 10^{5}\right)$ were centrifuged, resuspended in JC-1 solution and incubated at $37^{\circ} \mathrm{C}$ in $\mathrm{CO} 2$ incubator for $15 \mathrm{~min}$. At the end of the incubation period, cells were washed

Table1. Primer sequences for PCR amplification of target and reference genes

\begin{tabular}{llll}
\hline Primer & Sequence $\left(5^{\prime}-3^{\prime}\right)$ & Primer & Sequence (5'-3') \\
\hline Bax & (F) TTCCGAGTGGCAGCTGACAT & P21 & (F) GGAAGACCATGTGGACCTGT \\
& (R) TTCCAGATGGTGAGTGAGGC & & (R) GGCGTTTGGAGTGGTAGAAA \\
Bcl-2 & (F) GGTGAACTGGGGGAGGATTGT & P27 & (F) GCCCTCCCCAGTCTCTCTTA \\
& (R) CTTCAGAGACAGCCAGGAGAA & & (R) TCAAAACTCCCAAGCACCTC \\
P53 & (F) GTGGTTTCAAGGCCAGATGT & GAPDH & (F) CGGATTTGGTCGTATTGGG \\
& (R) GGCCCACTTCACCGTACTAA & & (R) TCTCGCTCCTGGAAGATGG \\
\hline
\end{tabular}


with incubation buffer and resuspended in incubation buffer, and kept on ice until FCM analysis.

Western blot analysis. A549 cells (6 x 106) were treated with $10 \mu \mathrm{g} / \mathrm{ml} \mathrm{TST}$ for $24 \mathrm{~h}$, then harvested and washed with cold PBS. Cell pellets were lysed in $40 \mu \mathrm{l}$ lysis buffer $(20 \mathrm{mM}$ HEPES/NaOH, pH 7.5, $250 \mathrm{mM}$ sucrose, $10 \mathrm{mM} \mathrm{KCl,} 2 \mathrm{mM}$ $\mathrm{MgCl} 2,1 \mathrm{mM}$ EDTA, $1 \mathrm{mM}$ DTT, protease inhibitor cocktail) for $20 \mathrm{~min}$ on ice. The lysis solution was centrifuged at $25000 \mathrm{~g}$ for $10 \mathrm{~min}$ at $4^{\circ} \mathrm{C}$, and protein contents in the supernatant were measured using a Bio-Rad DC protein assay kit. The lysates containing $25 \mu \mathrm{g}$ of protein were analysed by Western blotting for cytochrome $\mathrm{c}$ (1:1000 dilution).

Statistical analysis. All data are presented as the mean \pm S.D. (standard deviation from the mean). Differences between groups were evaluated using analysis of one-factor variance. Mean values were considered to be statistically significant at $p$ values $<0.05$.

\section{Results}

Main chemical component of TST. The chemical profile of TST extracts was analyzed using high performance liquid chromatography (HPLC) and was shown in Fig.1A. Com- pound c-1, c-2, c-3 accounted for about 3\%, $5 \%$ and $2 \%$ of TST, and total saponins for $80 \%$, determined by UV spectroscopy at $203 \mathrm{~nm}$, with complanatuside c- 2 as a standard. The purity of complanatuside A separated from FAC was more than $99.0 \%$, as shown by RP-HPLC with UV, and their structure was determined by IR, MS, NMR spectroscopy.

Effect of TST on cell proliferation. Effect of TST on cell proliferation was evaluated by MTT assay. As shown in Fig.1B, the inhibitory effect of TST in A549, Hela and MCF-7 cells was dose-dependent. When A549, Hela and MCF-7 cells were treated for $48 \mathrm{~h}$, the $\mathrm{IC}_{50}$ values of TST for each cell line were $4.11 \mu \mathrm{g} / \mathrm{ml}, 6.47 \mu \mathrm{g} / \mathrm{ml}$ and $7.78 \mu \mathrm{g} / \mathrm{ml}$, respectively. These results suggest that TST can inhibit the growth of A549, Hela and MCF-7 cells in vitro.

TST-induced DNA fragmentation in A549 cells. DNA extracted from A549 cells treated with TST at indicated concentrations $(10 \mu \mathrm{g} / \mathrm{ml})$ for $4,8,12,16,20$ and $24 \mathrm{~h}$ revealed a progressive increase in the 180-200bp ladder fragments. The ladder fragments began to appear after treated with TST for $20 \mathrm{~h}$ and the control cells did not exhibit any such DNA fragmentation. (Fig. 2A)

Morphology of apoptotic cells. In order to determine whether the antiproliferative effect of TST was due to apop-
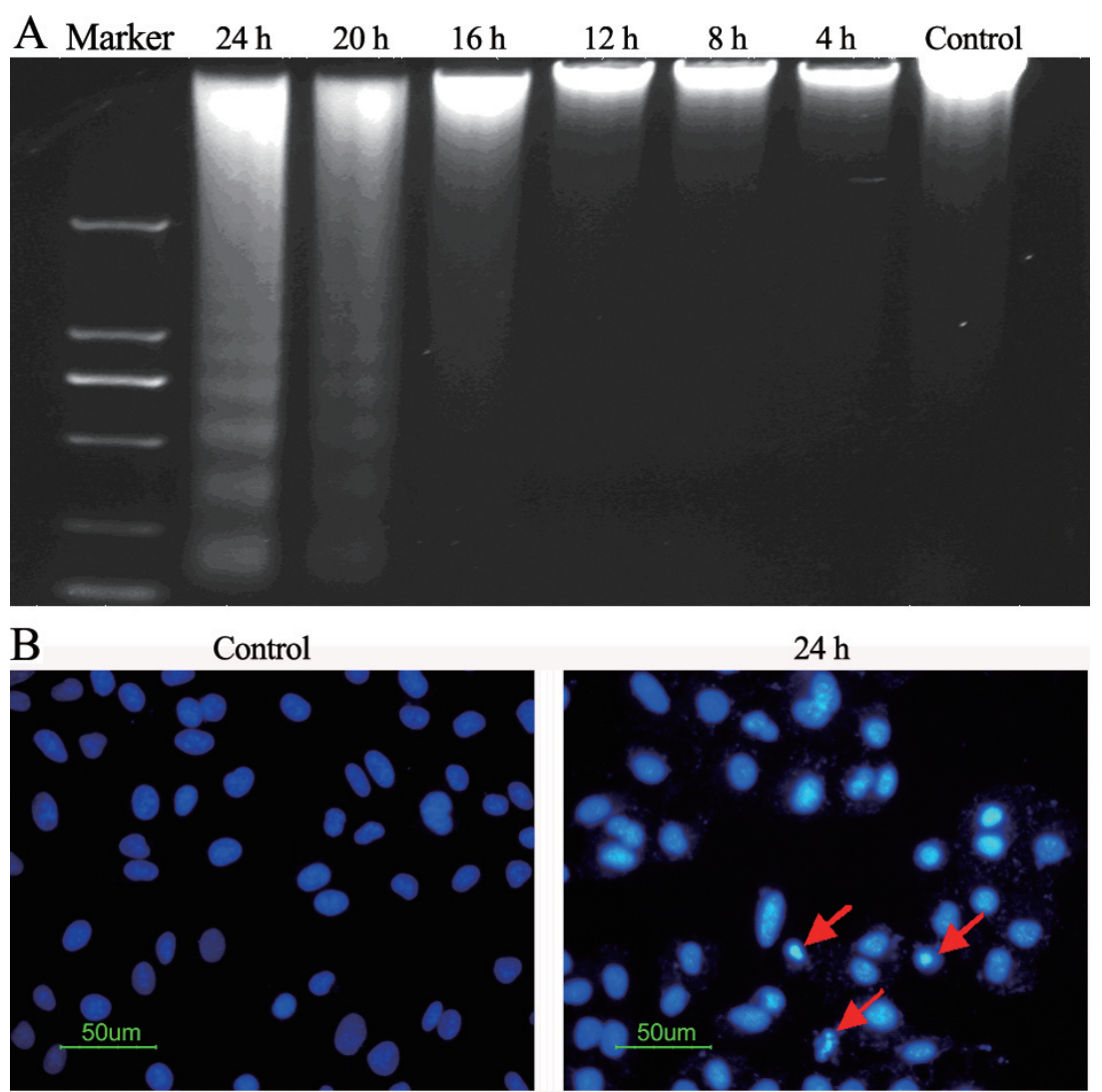

Figure 2. DNA fragmentation analysis and Hoechst 33258 staining observation. (A) When treated with $10 \mu g / \mathrm{ml}$ of TST for increasing time intervals, compared to control, increased oligonucleosomal DNA formation was observed in A549 cells. (B) Compared to control, cells treated with $10 \mu g / \mathrm{ml} \mathrm{TST}$ for $24 \mathrm{~h}$ showed condensed chromatin. Arrows indicate apoptotic bodies of nuclear fragmentation. (100×). 
tosis, A549 cells were treated with TST for $24 \mathrm{~h}$, and nuclear Hoechst 33258 staining was used. As shown in Fig. 2B, nuclei with condensed chromatin and apoptotic bodies were observed in A549 cells treated with TST, compared to the control. These results indicate that TST induced apoptotic cell death in A549 cells.

Flow cytometry analysis. After A549 cells were cultured with $10 \mu \mathrm{g} / \mathrm{ml}$ TST for 8,16 , and $24 \mathrm{~h}$, apoptotic cells appeared in the annexin $\mathrm{V}^{+} / \mathrm{PI}^{-}$fraction, whereas, cells damaged by scraping appeared in the annexin $\mathrm{V}^{-} / \mathrm{PI}^{+}$fraction, and late apoptosis or necrotic cells were evident in the annexin $\mathrm{V}^{+}$/ $\mathrm{PI}^{+}$fraction. The percentages of apoptotic cells (annexin $\mathrm{V}^{+}$/ $\mathrm{PI}^{-}$fraction) were $3.2 \pm 0.2 \%, 7.5 \pm 0.4 \%$, and $32.6 \pm 2.5 \%$, respectively (Fig.3A), compared to the control (3.4 $\pm 0.2 \%)$.

Effects of TST on activation of caspase-3, 9. The cellular pathway of TST-induced apoptosis was examined by assessing caspase-3, 9 activities, which play a critical role in apoptosis. After 2, 4, 6, 8, 10, 12, 16, 20 and 24 h treatment with $10 \mu \mathrm{g} / \mathrm{ml}$ TST, caspase-3, 9 activities of A549 cells were measured. Compared with untreated control cells, as shown in Fig.3B, A549 cells treated with TST for 0-24h showed significant time-dependent changes in caspase-3, 9 activities. These results suggested that TST-induced apoptosis occurred through the activation of common executors of apoptosis, such as caspase-3, 9.
Effect of TST on expression level of apoptosis and cell proliferation-related genes. As shown in Fig.4, the timecourse effects of TST on the apoptosis and cell cycle -related genes were explored. The Bcl-2 protein family controls apoptosis in mitochondria by balancing pro-and anti-apoptotic factors. We detected the pro-apoptotic member Bax and the anti-apoptotic member Bcl-2 by real time PCR. Bcl-2 mRNA expression was decreased but Bax gene expression was increased significantly in $10 \mu \mathrm{g} / \mathrm{ml}$ TST-treated cells at 2-8 h. Tumor suppressor gene P53 mRNAs was obviously increased in TST-treated cells at 1-12 h which has been shown to play an important role in apoptosis induction. In addition, cell proliferation-related genes P21 and P27 expression levels were also significantly increased, which have been known to play critical roles in the G1 to S phase cell cycle checkpoint.

Effect of TST on mitochondrial membrane potential (MMP). The effect of TST treatment on the mitochondrial membrane potential was determined by staining the cells with the dye JC-1, which accumulates in the mitochondria of living cells in a potential-dependent manner. From the results obtained, we found that upon the treatment of TST in A549 cells, there was a shift of fluorescence signal from the upper right quadrant to the upper left quadrant (Fig. 5A), indicating disruption of mitochondrial membrane potential. As can

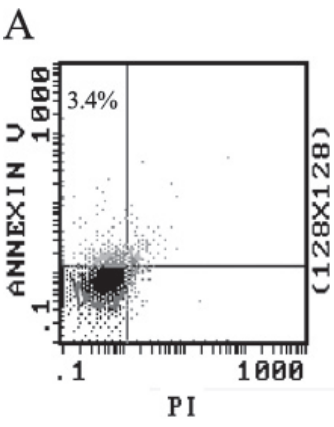

Control

B
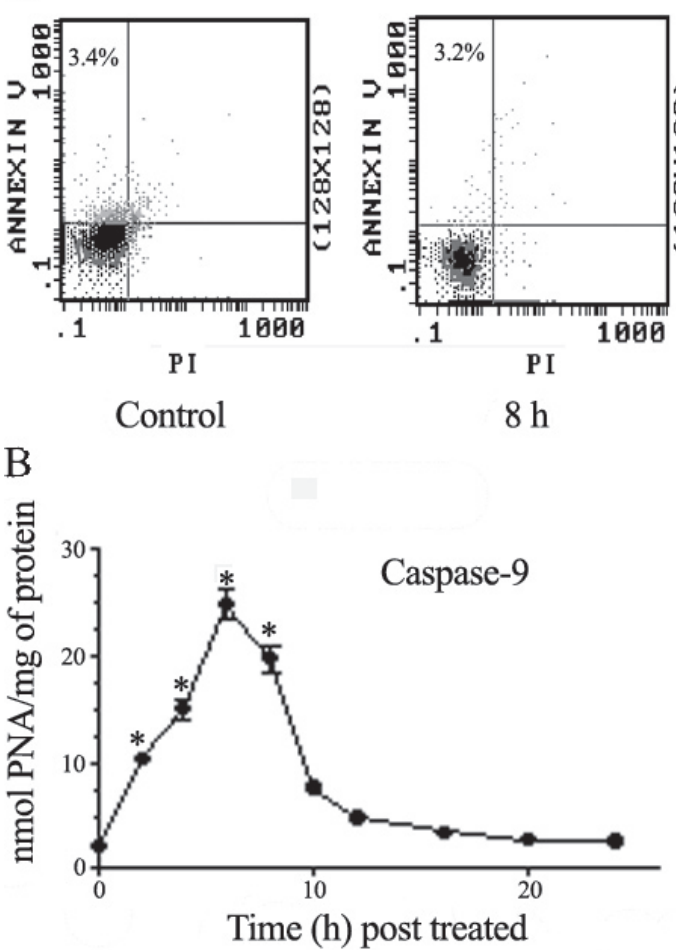

$8 \mathrm{~h}$

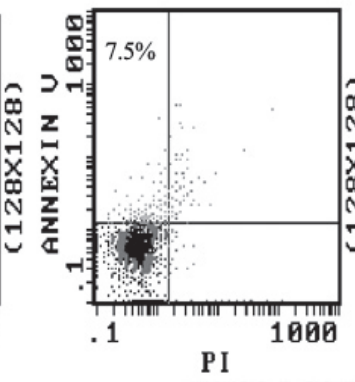

$16 \mathrm{~h}$

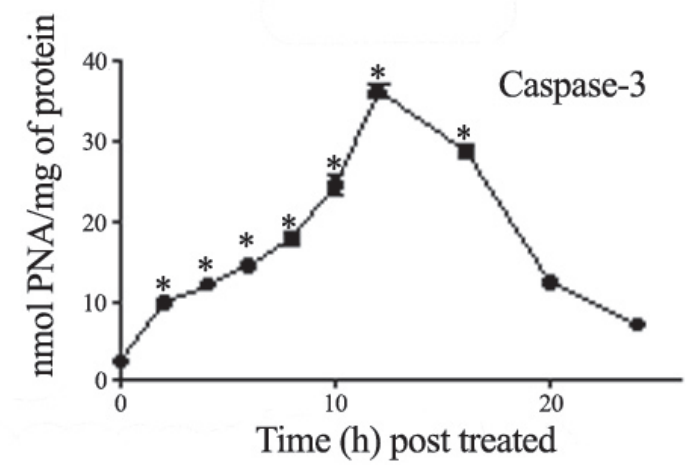

Figure 3. TST induced apoptosis by activation of caspase cascade inA549 cells. (A) A549 cell apoptosis increased in a time-dependent manner after treated with TST. ${ }^{\star} \mathbf{p}<0.05$. (B) The changes of caspases activities in A549 cells treated with $10 \mu \mathrm{g} / \mathrm{ml}$ TST were time-dependent. The data were represented as the $\mathrm{nmol} / \mathrm{mg}$ protein $p \mathrm{NA} .{ }^{*} \mathrm{p}<0.05$ vs. time 0 . 

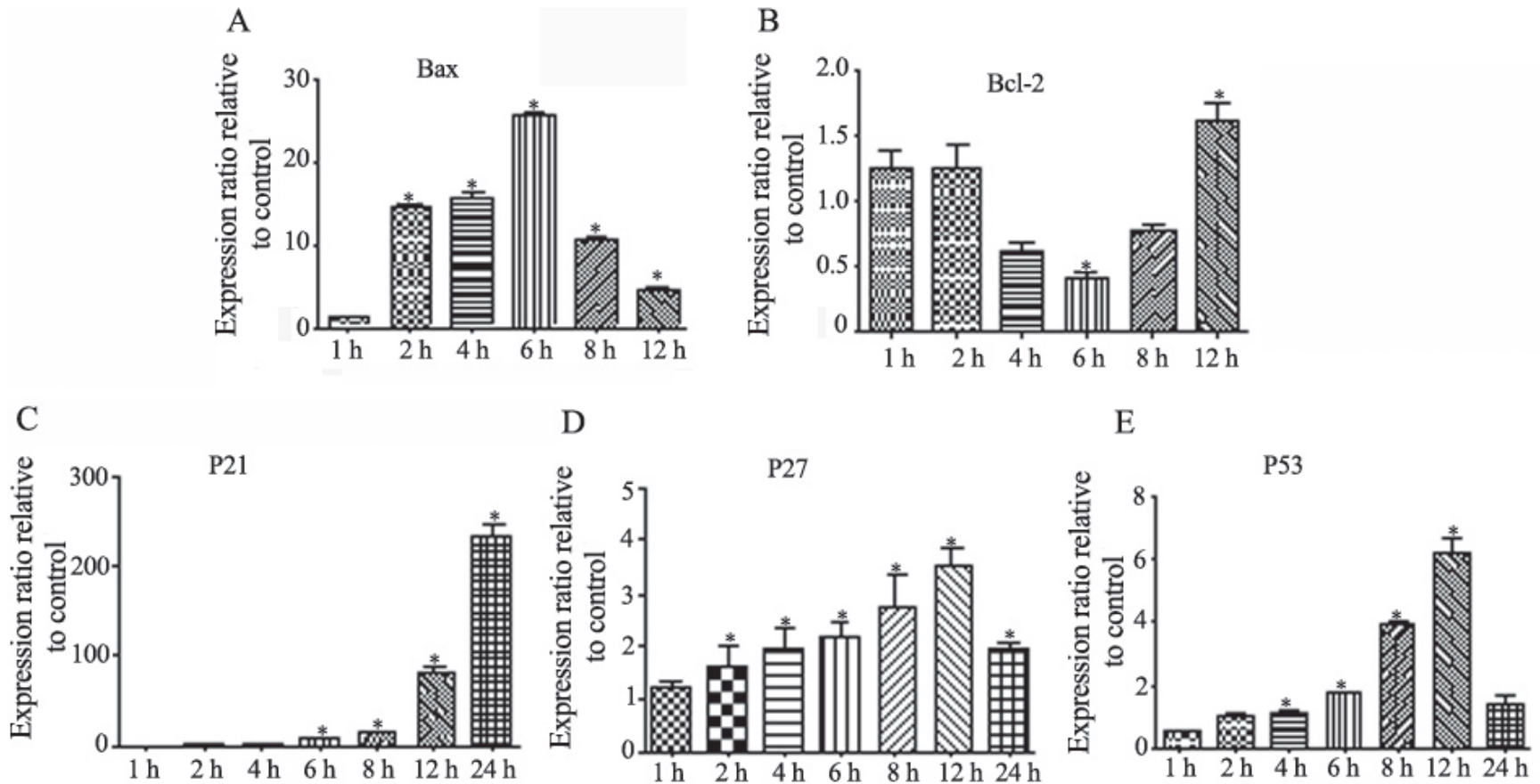

Figure 4. Kinetic effects of TST on apoptosis-related genes mRNA expression levels. The effect of TST on Bax (A), Bcl-2 (B), P21 (C), P27 (D) and P53 (E) mRNA expression was determined at the indicated time in A549 cells treated with TST $(10 \mu \mathrm{g} / \mathrm{m})$. Results were expressed in expression ratio of mRNA relative to control $(n=3) .{ }^{*} \mathbf{p}<0.05$.

be seen in Fig. 5B, TST treatment significantly decreased the mitochondrial membrane potential in a time-dependent manner, compared with the control.
Effects of TST on apoptosis related proteins of cytochrome $\mathrm{c}$. The release of cytochrome $\mathrm{c}$ from mitochondria into cytosol is an indicator of induction of mitochondria-de-
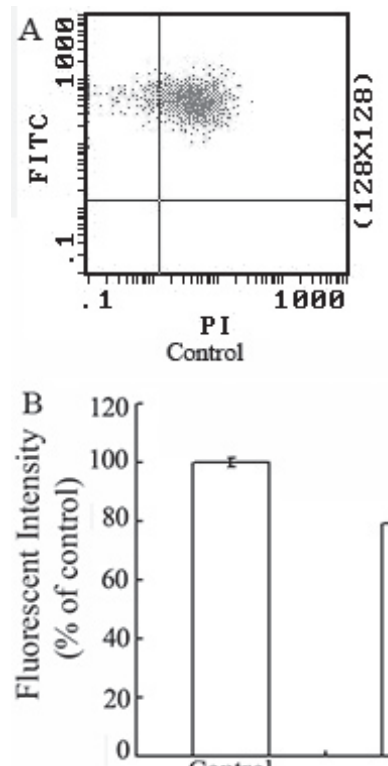

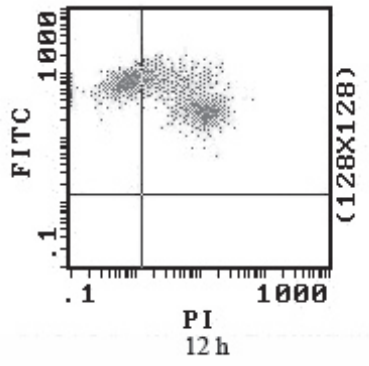

$\mathrm{C}$
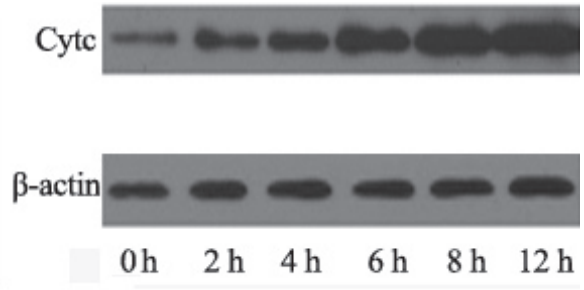

Figure 5. TST caused mitochondrial dysfunction and its effect on cytochrome c protein expression in A549 cells. (A) Results represented one of three independent flow cytometry examination. (B) Compare to control, after treated with TST for $12 \mathrm{~h}$ or $24 \mathrm{~h}$, the TST could decrease the $\Delta \Psi \mathrm{m}$ in a timedependent manner. ${ }^{\star} \mathrm{p}<\mathbf{0 . 0 5}$. (C) The expression of cytochrome $\mathrm{c}$ was increased in a time-dependent manner. 
pendent apoptotic pathway. To further examine the effects of TST on cytochrome $\mathrm{c}$, the protein level was evaluated using Western blot analysis. Fig.5C shows that cytochrome $\mathrm{c}$ in cytosol increased significantly when cells were exposed to 10 $\mu g / \mathrm{ml} \mathrm{TST}$ for $2 \mathrm{~h}$.

\section{Discussion}

Many substances derived from dietary or medicinal plants are known to be effective and versatile chemopreventive agents in a number of experimental models of carcinogenesis [17-20]. In present study, we found that the total saponins of Tupistra chinensis showed significant cytotoxic activity in several carcinoma cell lines in a dose-dependent manner. In addition, A549 cells were used in the research of apoptotic pathway due to this cell possessed the minimum $\mathrm{IC}_{50}$ value and appeared to be more sensitive to TST.

Cancer develops when the balance between cell proliferation and cell death is disturbed, and aberrant cell proliferation leads to tumor growth. Apoptosis is an important way to maintain cellular homeostasis between cell division and cell death $[1,2,21]$. Apoptosis and its related signaling pathways have a profound effect on the progression of cancer [22]. Induction of apoptosis is therefore a highly desirable goal of preventive strategies for cancer control [23]. In this respect, many studies were performed for screening of apoptosis inducing compounds from plants $[10,24,25]$. Saponins are a diverse family of secondary metabolites produced by many plants species. Many plants used in traditional medicine worldwide contain saponins, which can often account for their therapeutic action [26]. Although saponins are extremely toxic to cold-blooded animals, their oral toxicity to mammals is low $[27,28]$. Due to their toxicity to various organisms, saponins can be utilized for their anti-inflammatory, antibiotic, fungicidal, and antitumor pharmacological properties [26]. In the present study, we investigated whether apoptotic cell death is associated with antitumor activity of TST against A549 cells. The results of this study clearly demonstrate that TST suppressed A549 cell viability through apoptosis. During apoptosis, a distinctive series of morphological changes occurs, which involves cell shrinkage, loss of cell-cell adhesion, membrane blebbing, and chromatin condensation. These alterations are commonly associated with the internucleosomal DNA fragmentation, resulting from activation of endogenous nucleases. In this study, DNA fragment ladder formation was clearly observed, a characteristic gel electrophoretic band pattern associated with apoptosis. After A549 cells were treated with $10 \mu \mathrm{g} / \mathrm{ml}$ TST, nuclear condensations with Hoechst 33258 staining were clearly observed. Furthermore, early events in the apoptotic process are loss of plasma membrane asymmetry accompanied by translocation of phosphatidylserine (PS) from the inner to the outer membrane leaflet, thereby exposing PS which has a high affinity with annexin $\mathrm{V}$ to the external environment. Our results of flow cytometric analysis with annexin V-FITC and PI staining also validated TST-induced typical apoptosis in A549 cells.
The activation of a family of intracellular cysteine proteases, called caspases, is known to play a pivotal role in the initiation and execution of apoptosis induced by various stimuli $[29,30]$. Among the different members of caspases, Caspase- 3 and caspase- 9 play essential roles in death receptor as well as mitochondrial-mediated apoptotic pathways, respectively. Active caspase- 9 , in turn, activates caspase-3 which is an executioner caspase downstream of these caspases. Meanwhile, caspase- 3 may serve as a general mediator of apoptosis. When cells are undergoing apoptosis, caspase-3 triggers cellular proteins such as DNA fragmentation factor and results in the characteristic changes of apoptosis. Our results showed that during TST-induced apoptosis in A549 cells, caspase- 9 was activated firstly and a peak occurred after TST treated for $6 \mathrm{~h}$ and then caspase- 3 was activated after caspase- 9 activated with maximum changes when TST treated for $12 \mathrm{~h}$. These findings were in agreement with many studies that demonstrated the role of cysteine proteases family members in inducing apoptosis.

In this study, the mRNA expression levels of two apoptoticrelated genes, Bax and Bcl-2, in A549 cells treated with the TST were investigated. It was found that the expression levels of pro-apoptotic gene Bax was significantly up-regulated and maximum changes occurred after TST treatment for $6 \mathrm{~h}$. Antiapoptotic gene Bcl-2 was down-regulated slightly at $4-8 \mathrm{~h}$ after TST treatment. When Bcl-2 is overexpressed, it heterodimerizes with Bax, and cell death is repressed. Presumably, the ratio of Bax to Bcl-2 serves to determine the susceptibility of cells to apoptosis [21]. The mRNA expression levels of two cell proliferation-related genes, P21, P27and P53, in A549 cells treated with the TST were also investigated. Cell proliferation is governed by the cell cycle, which is one of the major causes of cancer progression, and their functions are tightly regulated by molecule P21, P27 and P53 that mainly inhibit cyclin-dependent kinases and thus have antiproliferative effects $[31,32]$. The results of gene assay in this study showed that P21 and P27 were up-regulated in the TST-treated A549 cells. And, pro-apoptotic gene P53 was also significantly upregulated after TST treatment for $8 \mathrm{~h}$. These findings suggest that the antiproliferative effect of TST in A549 cells may reflect changes in the expression levels of several genes related to the cell proliferation and apoptosis induction.

Mitochondria play a central role in the induction and control of apoptosis. Different apoptotic stimuli can converge at the mitochondrial level and trigger mitochondrial membrane permeabilization [33]. Membrane depolarization (loss of $\Delta \Psi \mathrm{m})$ induces mitochondrial permeability transition pore (PTP) formation. In our study, depletion of $\Delta \Psi \mathrm{m}$ in A549 cells was detected after treatment with TST for $12 \mathrm{~h}$ or $24 \mathrm{~h}$. This is consistent with our results that changes of the expression levels of Bax and Bcl-2 can disrupt the integrity of the outer mitochondrial membrane. Loss of mitochondrial membrane potential is catastrophic for cells and leads to release of cytochrome $\mathrm{c}$ through the mitochondrial PTP [34]. The data presented in our study indicated that TST treatment induces 
the migration of cytochrome $\mathrm{c}$ from the mitochondria to the cytosol.

In conclusion, this study clearly demonstrates that the total saponins of Tupistra chinensis strongly inhibit cell proliferation and induce apoptosis in A549 cells. TST induced apoptosis through the mitochondrial pathway, involving membrane depolarization and cytochrome $c$ release from the mitochondria, and the activation of caspases- 9 and- 3 . Because apoptosis was regarded as a new target in discovery of anticancer drugs, the results confirm the TST as a potential agent of chemotherapeutic in Human lung adenocarcinoma cell lines. However, further investigation of its activity including in vivo and purification of bioactive compounds is now in progress.

Acknowledgements: This work was financially supported by the National Natural Science Foundation of China (Grant No. 30670213, 30870254, 31070313) and the Natural Science Foundation of Hubei Province for innovation team (Grant No. 2007ABC008).

\section{References}

[1] KAUFMANN SH, HENGARTNER MO. Programmed cell death: alive and well in the new millennium. Trends Cell Biol 2001; 11: 526-534. http: //dx.doi.org/10.1016/S09628924(01)02173-0

[2] HENGARTNER MO. The biochemistry of apoptosis. Nature 2000; 407: 770-776. http: //dx.doi.org/10.1038/35037710

[3] LEE J, JUNG E, KIM Y, PARK J, HONG S, et al. Rosmarinic acid as a downstream inhibitor of IKK-beta in TNF-alpha-induced upregulation of CCL11 and CCR3. Br J Pharmacol 2006; 148: 366-375. http://dx.doi.org/10.1038/ sj.bjp. 0706728

[4] DAVIS DW, BUCHHOLZ TA, HESS KR, SAHIN AA, VALERO V, et al. Automated quantification of apoptosis after neoadjuvant chemotherapy for breast cancer: early assessment predicts clinical response. Clin Cancer Res 2003; 9: 955-960.

[5] SHINOMIYA N, SHINOMIYA M, WAKIYAMA H, KATSURA Y, ROKUTANDA M. Enhancement of CDDP cytotoxicity by caffeine is characterized by apoptotic cell death. Exp Cell Res 1994; 210: 236-242. http: //dx.doi.org/10.1006/ excr.1994.1035

[6] HAVRILESKY LJ, ELBENDARY A, HURTEAU JA, WHITAKER RS, RODRIGUEZ GC, et al. Chemotherapyinduced apoptosis in epithelial ovarian cancers. Obstet Gynecol 1995; 85: 1007-1010. http: //dx.doi.org/10.1016/ 0029-7844(95)00058-Y

[7] HUSCHTSCHA LI, BARTIER WA, ROSS CE, TATTERSALL $\mathrm{MH}$. Characteristics of cancer cell death after exposure to cytotoxic drugs in vitro. Br J Cancer 1996; 73: 54-60. http: //dx.doi.org/10.1038/bjc.1996.10

[8] GORCZYCA W, BIGMAN K, MITTELMAN A, AHMED T, GONG J, et al. Induction of DNA strand breaks associated with apoptosis during treatment of leukemias. Leukemia 1993; 7: 659-670.
[9] MOREIRA LF, NAOMOTO Y, HAMADA M, KAMIKAWA Y, ORITA K. Assessment of apoptosis in oesophageal carcinoma preoperatively treated by chemotherapy and radiotherapy. Anticancer Res 1995; 15: 639-644.

[10] TAN ML, SULAIMAN SF, NAJIMUDDIN N, SAMIAN MR,MUHAMMAD TS. Methanolic extract of Pereskia bleo (Kunth) DC. (Cactaceae) induces apoptosis in breast carcinoma, T47-D cell line. J Ethnopharmacol 2005; 96: 287-294. http: //dx.doi.org/10.1016/j.jep.2004.09.025

[11] CAI J, ZHU ZG, YU CL, LEI LS, WU SG. Saponin from Tupistra chinensis Baker inhibits mouse sarcoma S- 180 cell proliferation in vitro and implanted solid tumor growth in mice. Nan Fang Yi Ke Da Xue Xue Bao 2007; 27: 188-190, 194.

[12] PAN WB, WEI LM, WEI LL,WU YC. Chemical constituents of Tupistra chinensis rhizomes. Chem Pharm Bull (Tokyo) 2006; 54: 954-958. http://dx.doi.org/10.1248/cpb.54.954

[13] PAN WB, CHANG FR, WEI LM, WU YC. New flavans, spirostanol sapogenins, and a pregnane genin from Tupistra chinensis and their cytotoxicity. J Nat Prod 2003; 66: 161-168. http: //dx.doi.org/10.1021/np0203382

[14] ZHOU Y, ZOU K, YANG CY, WANG JZ. Determination of the Content of Total Saponin in Tupistra chinensis Bak. Lishizhen Med Mater Med Res 2007; 18: 2655-2656.

[15] BOYDRON-LE GARREC R, BENOIT E, SAUVIAT MP, LEWIS RJ, MOLGO J, et al. Ability of some plant extracts, traditionally used to treat ciguatera fish poisoning, to prevent the in vitro neurotoxicity produced by sodium channel activators. Toxicon 2005; 46: 625-634. http: //dx.doi.org/10.1016/ j.toxicon.2005.07.002

[16] MATSUI M, KUMAR-ROINE S, DARIUS HT, CHINAIN M, LAURENT D, et al. Pacific ciguatoxin 1B-induced modulation of inflammatory mediators in a murine macrophage cell line. Toxicon 2009; 56: 776-784. http://dx.doi.org/10.1016/ j.toxicon.2009.05.039

[17] SURH Y. Molecular mechanisms of chemopreventive effects of selected dietary and medicinal phenolic substances. Mutat Res 1999; 428: 305-327. http: //dx.doi.org/10.1016/S13835742(99)00057-5

[18] PARK KK, CHUN KS, LEE JM, LEE SS,SURH YJ. Inhibitory effects of [6]-gingerol, a major pungent principle of ginger, on phorbol ester-induced inflammation, epidermal ornithine decarboxylase activity and skin tumor promotion in ICR mice. Cancer Lett 1998; 129: 139-144. http: //dx.doi.org/10.1016/ S0304-3835(98)00081-0

[19] LEE E, PARK KK, LEE JM, CHUN KS, KANG JY, et al. Suppression of mouse skin tumor promotion and induction of apoptosis in HL-60 cells by Alpinia oxyphylla Miquel (Zingiberaceae). Carcinogenesis 1998; 19: 1377-1381. http://dx.doi. org/10.1093/carcin/19.8.1377

[20] THOMPSON HJ, JIANG C, LU J, MEHTA RG, PIAZZA GA, et al. Sulfone metabolite of sulindac inhibits mammary carcinogenesis. Cancer Res 1997; 57: 267-271.

[21] GREEN DR, REED JC. Mitochondria and apoptosis. Science 1998; 281: 1309-1312. http: //dx.doi.org/10.1126/ science.281.5381.1309

[22] LOWE SW, LIN AW. Apoptosis in cancer. Carcinogenesis 2000; 21: 485-495. 
[23] REED JC, PELLECCHIA M. Apoptosis-based therapies for hematologic malignancies. Blood 2005; 106: 408-418. http: //dx.doi.org/10.1182/blood-2004-07-2761

[24] CHENG YL, LEE SC, LIN SZ, CHANG WL, CHEN YL, et al. Anti-proliferative activity of Bupleurum scrozonerifolium in A549 human lung cancer cells in vitro and in vivo. Cancer Lett 2005; 222: 183-193. http: //dx.doi.org/10.1016/ j.canlet.2004.10.015

[25] PARK DI, LEE JH, MOON SK, KIM CH, LEE YT, et al. Induction of apoptosis and inhibition of telomerase activity by aqueous extract from Platycodon grandiflorum in human lung carcinoma cells. Pharmacol Res 2005; 51: 437-443. http: //dx.doi.org/10.1016/j.phrs.2004.11.003

[26] SPARG SG, LIGHT ME, VAN STADEN J. Biological activities and distribution of plant saponins. J Ethnopharmacol 2004; 94: 219-243. http: //dx.doi.org/10.1016/j.jep.2004.05.016

[27] DINI I, SCHETTINO O, SIMIOLI T, DINI A. Studies on the constituents of Chenopodium quinoa seeds: isolation and characterization of new triterpene saponins. J Agric Food Chem 2001; 49: 741-746. http: //dx.doi.org/10.1021/ jf000971y

[28] Dini I, TENORE GC, SCHETTINO O, Dini A. New oleanane saponins in Chenopodium quinoa. J Agric Food
Chem 2001; 49: 3976-3981. http://dx.doi.org/10.1021/ jf010361d

[29] DATTA R, KOJIMA H, YOSHIDA K, KUFE D. Caspase-3mediated cleavage of protein kinase $\mathrm{C}$ theta in induction of apoptosis. J Biol Chem 1997; 272: 20317-20320. http: //dx.doi. org/10.1074/jbc.272.33.20317

[30] LIU X, ZOU H, SLAUGhter C,WANG X. DFF, a heterodimeric protein that functions downstream of caspase-3 to trigger DNA fragmentation during apoptosis. Cell 1997; 89: 175-184. http: //dx.doi.org/10.1016/S00928674(00)80197-X

[31] TOYOSHIMA H, HUNTER T. p27, a novel inhibitor of G1 cyclin-Cdk protein kinase activity, is related to p21. Cell 1994; 78: 67-74. http: //dx.doi.org/10.1016/0092-8674(94)90573-8

[32] FANG Y, YU S, BRALEY-MULLEN H. TGF-beta Promotes Proliferation of Thyroid Epithelial Cells in IFN-gamma(-/-) Mice by Down-Regulation of p21 and p27 via AKT Pathway. Am J Pathol 2011.

[33] SUEN DF, NORRIS KL, YOULE RJ. Mitochondrial dynamics and apoptosis. Genes Dev 2008; 22: 1577-1590. http: //dx.doi. org/10.1101/gad.1658508

[34] KROEMER G, REED JC. Mitochondrial control of cell death. Nat Med 2000; 6: 513-519. http: //dx.doi.org/10.1038/74994 